\title{
CHARACTERIZATION OF THE COMMUNITY PARTICIPATION MODEL IN THE MOSQUE CONSTRUCTION PROCESS (CASE STUDY: CONSTRUCTION OF MOSQUES IN DENMARK REGENCY)
}

| Received November 15th 2018 | Accepted January 30th 2019 | Available online June 30th 2019 | DOI http://dx. doi. org/10.18860/jia.v5i3.5791

\section{Mohhamad Kusyanto}

Doctoral Program in Architecture,

School of Architecture,

Planning and Policy Development Institut Teknologi Bandung, Indonesia mkusyanto@gmail.com

\section{Sugeng Triyadi}

Architecture Department.

School of Architecture,

Planning and Policy Development

Institut Teknologi Bandung, Indonesia

sugengtriyadis@gmail.com

\section{ABSTRACT}

This research is based on the phenomenon of community participation in the development of domed mosques in Indonesia. Community participation was identified based on capability and the nature of the community. This paper compares the involvement of people in coastal areas of Demak to the participation of people in Demak city center in Central Java, Indonesia. Data was collected through interviews with the community and stakeholders in the construction of the mosques. The results of the study indicate there are differences in the communities' capabilities, especially concerning financing and knowledge. Different characteristics also in the total floor area of the mosque building that was built by the community. These differences have an impact on the length of time needed to construct the mosque.

\section{KEYWORDS:}

Development with community participation, construction management, domed mosque, Demak

School of Architecture,

Planning and Policy Development

Institut Teknologi Bandung, Indonesia

surjamanto.wonorahardjo@gmail.com

*) corresponding author

\section{INTRODUCTION}

Domed mosques are a popular type of mosque that so many are built with community participation in Demak Regency. The construction of this type of mosque is based on the community's desire to have a proper mosque in their area as a place to prostrate [1], a place to gather in prayer as a congregation [2], a place to carry out all Muslim activities related to obedience to God [1] and a means to serve Allah SWT [3].

Mosques built with community involvement [4] are generally designed without input from architects [5]. Community involvement [6] in the development process represents the community's willingness and ability to contribute [7].

Mosque development accompanied by community participation essentially places the community as a decision maker when performing related activities. Community contributions include direct participation in the building process, attention, and financial contributions from the community [8]. The Developments with community participation are initiated and carried out by the community, and the results are enjoyed by the community [9]. Development with community participation is a process in which community members act as stakeholders, allowing them to influence and control the development [10]. This participation represents the voluntary action of each people to seize opportunities and assuming social responsibility [11].

Demak Regency, one of the regencies in Central Java, Indonesia, is located at coordinates 6 $43^{\prime} 26^{\prime \prime}-$ $7^{\circ} 09^{\prime} 43^{\prime \prime} \mathrm{S}, 110^{\circ} 27^{\prime} 58^{\prime \prime}-110^{\circ} 48^{\prime} 47^{\prime \prime} \mathrm{E}$. It is located on the northern coast of Java Island, which consists of four administrative sub-districts: Wedung District, Bonang District, Sayung District and Karangtengah District with a total of 78 villages and an overall area of $312.24 \mathrm{~km} 2$ (Figure 1).

Coastal areas are transitional areas between land and sea [12], [13], [14], which include distance from the coastline to the land and the distance to the ocean [15]. The area inland from the coast contains both dry and submerged land that is still influenced by the properties of the sea such as tides, sea breezes, and saltwater permeation. The coastal area includes part of the sea, which is still affected by natural processes that occur on lands, such as sedimentation and freshwater flow and the influence of land-based human activities, such as deforestation and pollution[16].

The downtown area of Demak is the seat of the Demak Regency government. The city center area has 
many designations, namely 'urban center', or 'urban core', 'central business district', or 'complex area of government' or 'civic center' [17].

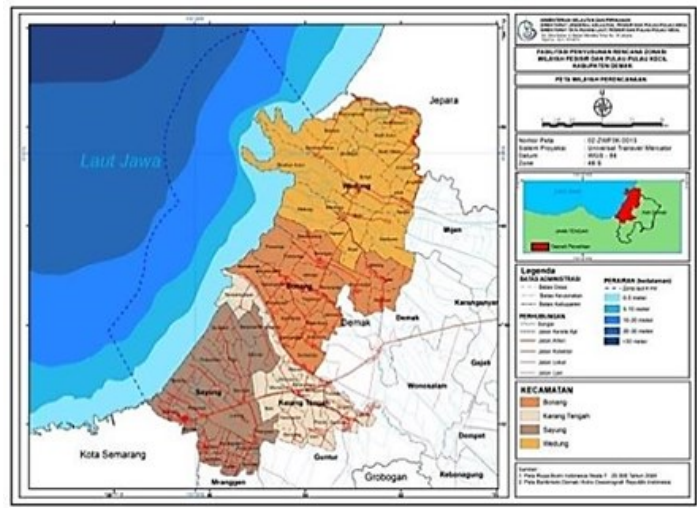

Figure 1. Coastal area of Demak Regency

Map source : Rencana Zonasi Wilayah Pesisir dan Pulau-Pulau Kecil (RZWP3K) Demak regency, 2013

A city center is generally a place where commercial activities are concentrated, and it accommodates the main urban events [18] and forms the center of urban settlements [19]. According to Bourne [20], the city center is the core of a city that was initially a settlement that later developed into an administrative, commercial, and communication center called the central business district (CBD).

Dome mosques built by local people who inhabit the village area. The management of the mosque is carried out by the mosque manager. In the construction of mosques, the mosque manager formed a construction committee responsible for the construction of the mosque. The construction committee consists of elements of the mosque's management and the chosen community through a joint meeting process. The construction committee drives community participation to absorb the potential of the region's natural resources and human resources. The construction committee carried out the construction from the design, the process to completion.

Based on the above factors, the coastal region and the city center is exciting and essential to research the characteristics of community participation in the building construction process. The objective of this study is to know the building process. Especially as it relates to the construction of a domed mosque, thereby improving the participatory process in future developments since it falls by the character of the community.

\section{METHODS}

This research was conducted at domed mosques in Demak Regency. Determination of the sample using purposive sampling method, which is the selection of samples using criteria by the objectives of the study. The population of mosques in Demak regency is 698 mosques in 294 villages. The mosque built by the gov- ernment amounted to Jami Sultan Fatah mosque in Jogoloyo Wonosalam Demak, while the community made the other mosques.

The oldest and largest mosques in each village are selected as a sample in this study. The results of the sample selection showed $34.14 \%$ of mosques with modern domes, $18.47 \%$ of mosques with front porches with main domes roofed with canopy roofs, $14.46 \%$ of mosques combined with pyramid, canopy, and dome, $8.43 \%$ mosques with flat concrete foyers - main canopy space and $24.59 \%$ of mosques with canopy porches canopy main rooms. This sample is grouped into two major groups, namely domed mosques of $67.07 \%$ and domed mosques of $32.93 \%$.

The object of the research was carried out at a modern domed mosque. It is consistent with the purpose of the study to see technical reliability in the process of community participation, so as not to analyze non-modern mosques. The research object was chosen by seven coastal mosques and seven mosques in the city center. Seven mosques are located on the coast, namely Al-Falah Betahwalang, Al-Mubarok Margolinduk, Baitur Rohman Purworejo, Jami 'Purwosari Sayung, Al-Azar Jungpasir, An-Nur Kedungkarang, and Baitul Ma'mur Kedungmutih; seven mosques are in the city center, namely Nurul Huda Kalicilik, Jami 'Al-Huda Bolo, Baitul Muttaqin Cabean, Al-Barokah Kedondong, Jami' At-Taqwa Mulyorejo, Al-Idris Raji, and Jami Baitul Muttaqin Turirejo (Figure 1).

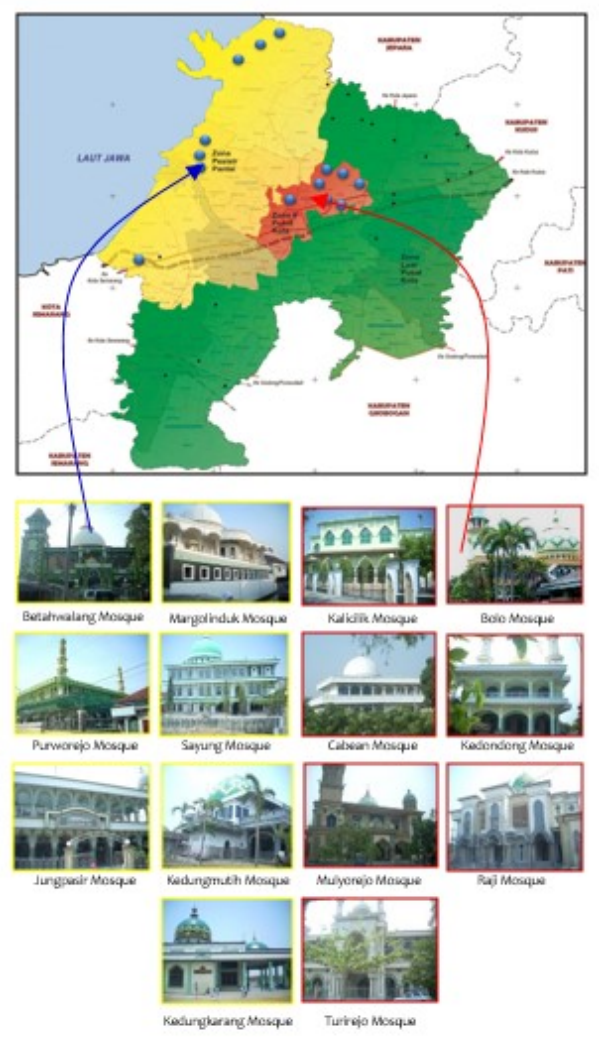

(a)

(b)

Figure 2: Distribution of domed mosques in Demak Regency: (a) the coast (yellow square), (b) city centre (red square) Map source: Rencana Tata Ruang Wilayah (RTRW) Demak regency, 2010-2030 
In this study, quantitative exploratory methods were used [21] [22]. Data were collected via in-depth interviews to obtain the right information through several layers of confirmation from other respondents. They are the community, community leaders, and the committee, regarding the construction of the 14 coastal and city mosques in Demak Regency. Data collection obtained is secondary data because the development process has long happened.

The type of interview used is a semi-structured interview, which uses interview guidelines that have been systematically compiled, listened carefully and recorded what was stated by the respondents. The analysis was carried out in a questionnaire analysis, which analyzed the data from the questionnaire by comparing the community participation in the two regions arranged in the analysis variables.

\section{DISCUSSION}

Coastal areas and city centers have different characteristics of community participation. Participation is distinguished by money, building materials, or labour. For community participation on the coast, $57 \%$ is money, and $43 \%$ is construction labour. For the city, $71 \%$ is money, and $29 \%$ is construction labour (Figure 3 ). It shows that people in cities are more willing to contribute money rather than labour. Donations of money are more comfortable for the mosque construction committee to complete construction because it gives the committee more flexibility than having to manage donations of building materials. The selection of building materials in the development process requires excellent communication between parties - for example, the community and the building committee - so that building materials are not wasted.

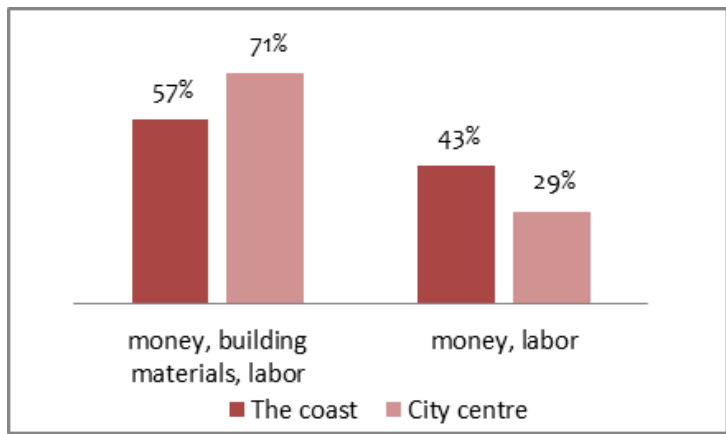

Figure 3.: Forms of community participation in coastal areas and city centre

There are two types of funding sources for mosque construction, which are, the community selfhelp and the government assistance. In coastal areas, $57 \%$ of mosques are built with funds that come purely from community self-help and the remaining $43 \%$ receive a little government assistance. In contrast, $43 \%$ of mosques in the city center are built with funds provided purely by the community and the remaining $57 \%$ receive a small amount of funding from the government (Figure 4). It shows that the construction of mosques in Demak Regency was funded more by the community itself and that the role of the community in assisting is very significant. It also shows that community-funding capabilities in cities are higher than those in coastal areas.

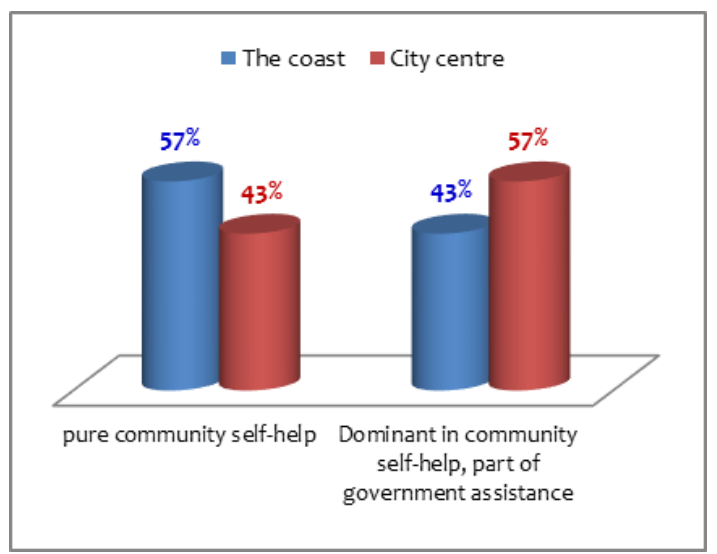

Figure 4. Sources of funding for the construction of domed mosques on the coast and city

The mosque construction committee determines the technical and development team that is placed in the field. The technical team is the expert in charge of controlling the technical construction of the mosque and the development executor carrying out the construction consists of artisans and workers. In $72 \%$ of cases, the technical team that helped the mosque construction committee in the coastal areas mainly came from their villages. $14 \%$ came from other villages, and the remaining $14 \%$ came from a combination of villages. In contrast, development in the city center relies on a technical team that comes entirely from the region itself (Table 1). It shows that the technical capacity of labour in the city center is better than in the coastal areas.

Table 1: Origin of the technical team for the construction of mosques on the coast and city centre

\begin{tabular}{lccc}
\hline Region & Own Village & $\begin{array}{c}\text { Another } \\
\text { Village }\end{array}$ & Combined \\
\hline The Coast & $72 \%$ & $14 \%$ & $14 \%$ \\
City Centre & $100 \%$ & $0 \%$ & $0 \%$ \\
\hline
\end{tabular}

The technical teams assigned to building construction in each region have different levels of education. Technical teams in coastal areas have $29 \%$ undergraduate education levels, while $29 \%$ have a high school level and the remaining $42 \%$ have an elementary school level. In the city, these percentages were $29 \%$, $42 \%$ and $29 \%$, respectively (Table 2 ). It shows that the education level of the technical team in the city center is higher compared to the group in the coastal area.

The origin and level of education of the technical teams represent the community's ability to manage the construction of the mosque. This ability also influences the quality of the finished mosque building. 
Table 2: Educational level of the technical team on the coast and city centre

\begin{tabular}{lccc}
\hline Region & Bachelor & High School & $\begin{array}{c}\text { Elementary } \\
\text { School }\end{array}$ \\
\hline The Coast & $29 \%$ & $29 \%$ & $42 \%$ \\
City Centre & $29 \%$ & $42 \%$ & $29 \%$ \\
\hline
\end{tabular}

In addition to the technical team, mosque construction workers or artisans are also involved. As much as $43 \%$ of development in the coastal area relies on artisans originating from other villages, and as much as $57 \%$ is combined with labour from other villages. In contrast, $42 \%$ of mosque construction in the city center relies on local artisans, $29 \%$ of labour comes from different villages, and as much as $29 \%$ comes from a combination of several villages (Table 3). It shows that the human resources available in the city center are better than on the coast.

Table 3: Origin of artisans/workers on the coast and city centre

\begin{tabular}{lccc}
\hline Region & Own Village & $\begin{array}{c}\text { Another } \\
\text { Village }\end{array}$ & Combined \\
\hline The Coast & $0 \%$ & $43 \%$ & $57 \%$ \\
City Centre & $42 \%$ & $29 \%$ & $29 \%$ \\
\hline
\end{tabular}

The mosque-building process follows the drawing guidelines designed by the building committee. Design of the mosque presented to the community before it was built on the wakaf land of the mosque. The means of creating the initial design of each domed mosque in the two regions are different. For mosques on the coast, $57 \%$ already had initial designs, and $43 \%$ did not have initial designs, whereas in the city, $86 \%$ had initial designs and $14 \%$ did not (Figure 5). It shows that the construction of mosques in the city has better development planning than development in coastal areas. The presence of this initial design implies a building design under the planning of the building committee. Design changes often occur throughout the development process but do not result in changes to the overall design. When the mosque building does not have an initial design, the construction process changes at each stage. It is generally considered to produce a mosque that does not follow the planning of the building committee.

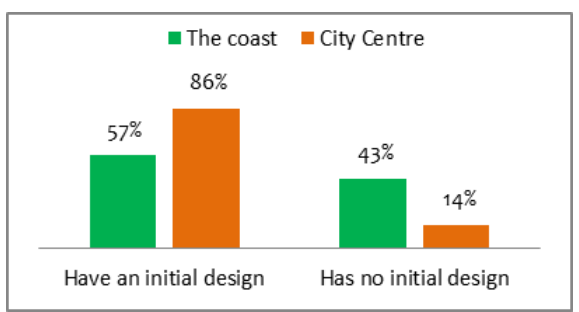

Figure 5. The initial design of mosques on the coast and city centre
Mosque construction on the coast was carried out $40 \%$ in stages, beginning with the construction of the main space and continuing with the construction of the porch. Instead, $86 \%$ of mosque construction on the coast occurs by completely dismantling the old building. Nearly the same situation is seen in the city center, where gradual development was carried out for as many as $29 \%$ of mosques, and $71 \%$ were built after completely dismantling the old building.

It shows that in both the coastal and the city center areas, mosques were more likely to be built by dismantling old mosques (Figure 6). The construction of the mosque from the beginning makes it easier to build a mosque according to design. It reduces the difficulty of phasing and management at the site, especially for the placement of building materials.

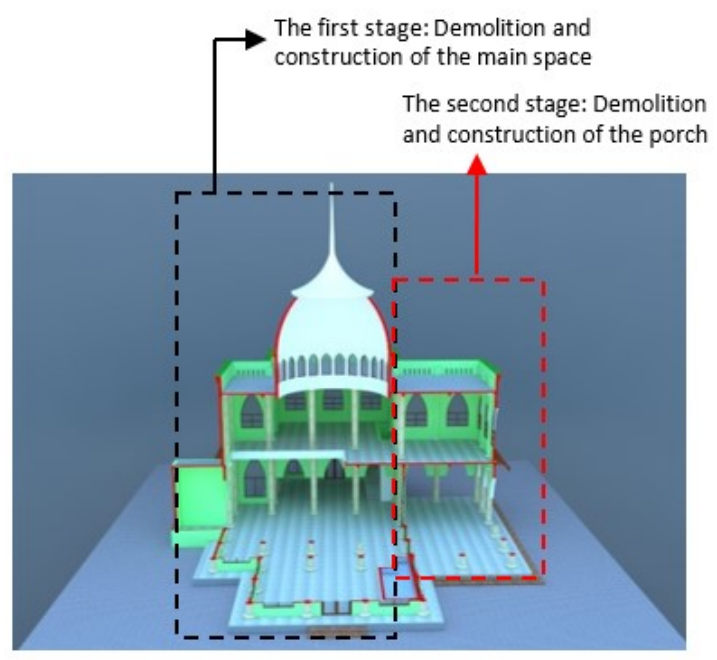

Figure 6. The process of construction of the Kalicilik mosque in the city centre

The mosque-building process in coastal areas can generally be divided into two areas: the construction managed by the community and the construction contracted to a third party. The construction of $57 \%$ of mosques on the coast was done independently by the community, and the remaining $43 \%$ had assistance from a third party. As for the construction of mosques in the city center, $71 \%$ were self-managed, and only $29 \%$ were assisted by third parties. (Figure 7).

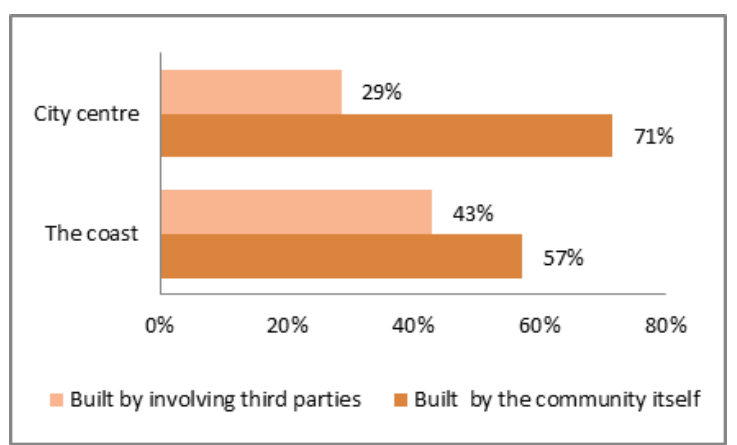

Figure 7. Strategy for implementing the construction process of mosques on the coast and city centre

162 | Journal of Islamic Architecture, 5(3) June 2019 
The results of this study indicate that different management systems are applied in the self-help system of mosque construction. Some of the development committees implemented participation scheduling in each Rukun Tetangga/Rukun Warga (RT/RW), and some did not (total community contributions). Eighty-six per cent of mosques in coastal areas carried out construction without scheduling and the remaining $14 \%$ implemented programming per RT/RW. Unlike the process of mosque construction in the city center, the construction system with scheduling is preferred. Fiftyseven per cent of development committees in the city implemented scheduling per RT/RW, and the remaining $43 \%$ applied the method without scheduling (Figure 8 ).

The results of this analysis show that urban communities are more capable of scheduling construction, so it is not necessary to involve third parties in constructing the mosque. Unlike coastal communities, the percentage of work done by third parties is higher because local residents do not have the expertise to carry out the work.

In the city, the management of mosque construction workers with a scheduling system is based on the type of work and the worker expertise needed. In contrast, for coastal areas, the management of workers without scheduling is based on the principle of solidarity and harmony among community members. Although there are difficulties in regulating labour at the site, so many workers are less effective.

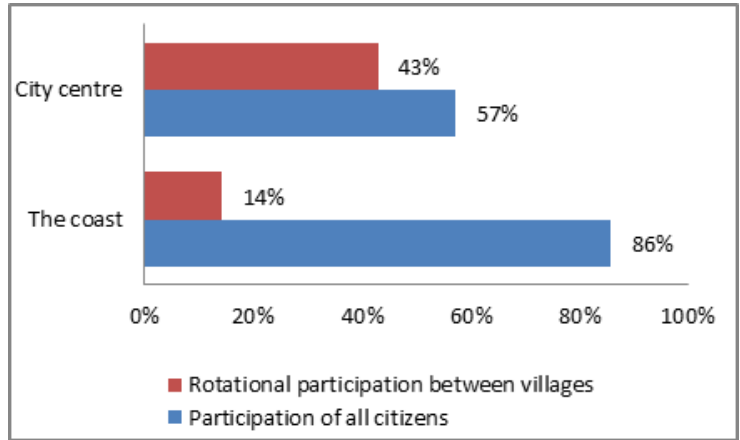

Figure 8. Manpower management with a cooperation system on the coast and city centre

The ability of the mosque building committee to manage to fundraise also differs communities on the coast and in the city center. This capability determines the duration of building construction such that the construction of mosques on the coast lasts longer than construction in the city center. It shows that the urban community has better managerial ability to raise funds compared to coastal communities. The average duration of construction of the mosque on the coast is 16 years, while it is six years in the city (Figure 9).

The results of this analysis also show that the financial capacity of the community influences the duration of mosque construction. In general, urban communities have better capabilities related to finances, materials, and expertise, so the construction process is completed sooner.

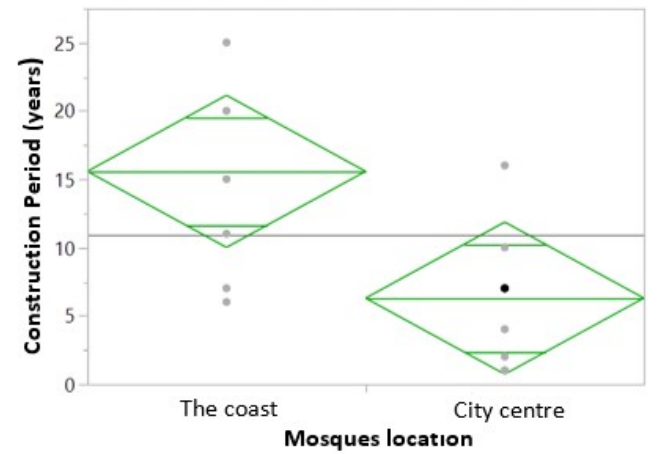

Figure 9. Period of construction of mosques on the coast and city centre

In the process of building a mosque, the building floor area is one of the factors that must be considered by the community. The domed mosque built by the coastal community has a total floor area of all $6,764 \mathrm{~m}^{2}$ with an entire building duration of 109 years so that the average annual building is $62 \mathrm{~m}^{2} /$ year. Domed mosques in the downtown area have a total floor area of all $5,567 \mathrm{~m} 2$ of mosques with a total building duration of 44 years so that the annual average builds 127 $\mathrm{m} 2$ / year (Table 4).

Table 4. Total building floor area and duration of construction

\begin{tabular}{lccc}
\hline Mosque & $\begin{array}{c}\text { Total Floor } \\
\text { area }\left(\mathrm{m}^{2}\right)\end{array}$ & $\begin{array}{c}\text { Total } \\
\text { building } \\
\text { duration }\end{array}$ & $\begin{array}{c}\text { Annual } \\
\text { average } \\
\text { builds }\left(\mathrm{m}^{2} /\right.\end{array}$ \\
\hline The Coast & 6,764 & 109 & 62 \\
City Centre & 5,567 & 44 & 127 \\
\hline
\end{tabular}

In the community building process, there is a correlation between the floor area and the time needed to complete it (Figure 10). Financial and knowledge of community influence the construction period of the mosques. The community of the city can complete the development in a shorter period than the community of coastal areas.

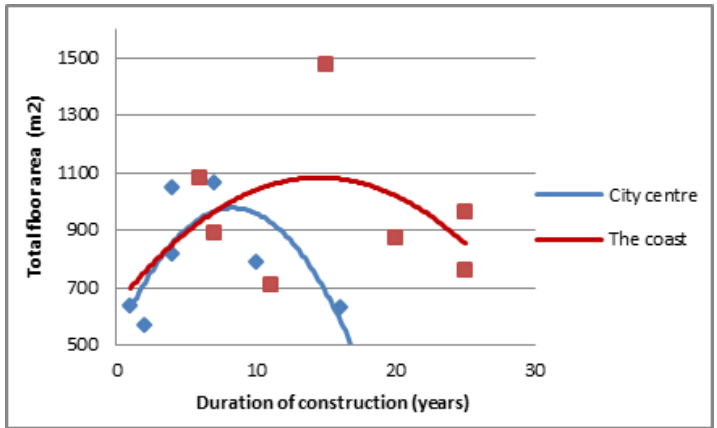

Figure 10. Time-dependent floor area curve for the city centre and the coastal 
Community participation in mosque construction on the coast and the city center in Demak Regency is influenced by the community's ability regarding financing and knowledge. Financial aspects include contributions and sources, while elements of community knowledge include environmental factors related to the technical team/worker and level of education. The business and learning aspects of the community form the basis for other building aspects, namely those related to creating the initial design, the choice of construction systems and techniques, and the selection of procedures for community participation. Overall, these aspects were measured by the length of time needed to complete construction of the mosque (Figure 10).

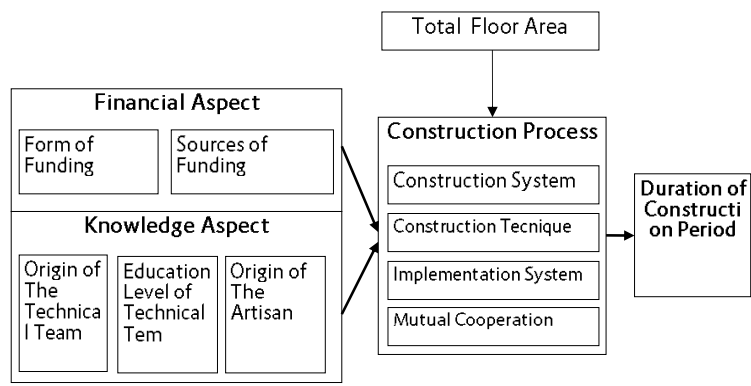

Figure 10. Relationship of community capacity, building process and duration of construction

Community participation [23] can be divided into two stages, that is, the planning process and the construction process [24]. In the planning process, the community participates in designing the mosque by offering ideas. Contributions were provided during the meeting to develop the initial mosque design and fundraising. In the construction process, on the other hand, community contributions are given directly during the process.

\section{CONCLUSION}

Most mosques are built and expanded by the people themselves without government support. This research provides a new understanding of and knowledge about the model of community participation in development, especially regarding the construction of mosques in Indonesia. Community participation is an approach to construction development whose effectiveness can be measured via the duration of the construction process.

The study indicates differences in character and ability of the community to construct buildings on the coast and in the city center. The difference in character lies in the decisions made by the construction committee. Coastal communities prefer to involve third parties in the construction process to fulfil technical construction matters that they do not understand. They also do not prioritize work schedule because the value of solidarity is considered to be more critical. City people are better at scheduling work because of the limited time they have. Less third party involvement in urban communities shows better technical construction capabilities in the community.

In general, it can be concluded that the approach to development with community participation by Indonesian culture. The modernization of urban communities has not eliminated the culture of cooperation. The limitations of working time in cities are overcome by managing and scheduling construction. The community participation approach did not have a negative impact on the quality of the mosque buildings because the aspects of construction techniques that were not controlled were approached well by inviting outside parties to participate.

The community-participation approach is still relevant for implementation in Indonesia today both in urban and coastal communities. It can be expanded as a development model that is good and appropriate for the people of Indonesia.

\section{ACKNOWLEDGEMENT}

The author would like to thank the promoters and copromoters of doctoral programs in the architecture study program, SAPPK ITB who have provided dissertation guidance. Also, to the Indonesian Ristekdikti who have provided funding through the Doctoral Dissertation Research Grant (PDD) program in 2018.

\section{REFERENCES}

[1] M. Q. Shihab, Wawasan Al Qur'an. Bandung: Penerbit Mizan, 1997.

[2] M. E. Ayub, Manajemen Masjid: Petunjuk Praktis bagi Para Pengurus. Jakarta: Gema Insani Press, 1996.

[3] Siswanto, Panduan Praktis Organisasi Remaja Masjid. Jakarta: Pustaka Al Kautsar, 2005.

[4] I. Serageldin, "Contemporary Expressions of Islam in Building: The religious and the Secular," 1990.

[5] P. Faqih, M., Prijotomo, J., Sulistyowati, M. dan Setijanti, Tipologi Arsitektur Masjid-TanpaArsitek. Surabaya: Laporan Penelitian Tidak Diterbitkan, Lembaga Penelitian Institut Teknologi Sepuluh Nopember, 1992.

[6] Isbandi, Perencanaan Partisipatoris Berbasis Aset 
Komunitas: dari Pemikiran Menuju Penerapan. Depok: FISIP IU Press, 2007.

[7] R. Adisasmita, Pembangunan Pedesaan Dan Perkotaan. Yogyakarta: Graha Ilmu, 2006.

[8] S. Pasaribu, C., Sosiologi Pembangunan. Bandung: Transito, 2005.

[9] S. Suparjan, Pengembangan Masyarakat, dari Pembangunan sampai Pemberdayaan. Yogyakarta: Aditya Media, 2003.

[10] D. Tikson, Ekonomi Terpadu dan Partisipasi Pembangunan Masyarakat. Makassar: Materi Kuliah Program Pascasarjana Unhas, 2001.

[11] C. Tosun, "Limits to community participation in the tourism development process in developing countries," vol. 21, pp. 613-633, 2000.

[12] R. et al Dahuri, Pengelolaan Sumberdaya Pesisir dan Lautan Secara Terpadu. Jakarta: PT. Pramadya Paramita, 1996.

[13] L. De Puydt, A. Gladytz, and L. Karrasch, "Developing sustainable coastal areas: A comparison between the Netherlands and the United Kingdom," pp. 24-55, 2007.

[14] S. R. Lakshmi and P. S. T. L, "Transformation of Coastal Settlements Due To Tourism," vol. 24, pp. 1668-1680, 2016.

[15] D. A.A., “Model Pengelolaan Wilayah Pesisir Ka- bupaten Berbasis Digital (Studi Kasus: Kabupaten Cilacap Jawa Tengah)," in Temu Alumni MPKD, 2004.

[16] S. Budiharsono, Teknik Analisis Pembangunan Wilayah Pesisir dan Lautan. Jakarta: PT Pradnya Paramita, 2001.

[17] H. Damayanti, R., "Kawasan 'pusat kota' dalam perkembangan sejarah perkotaan di jawa," vol. 33, no. 1, pp. 34-42, 2005.

[18] B. Prasetyo, N., Pugawati, "Evaluasi kesesuaian fungsi pusat kota Wonosobo sebagai pusat pelayanan," J. Tek. PWK, pp. 1-9, 2013.

[19] P. Mitkovi and M. Dini, "City center organization and its influence on the city structure," vol. 3, no. 45, pp. 41-56, 2004.

[20] L. S. Bourne, Internal Structure of The City. New York: Oxford University Press, 1982.

[21] J. W. Creswell, Research Design: Qualitative, Quantitative, and Mixed Methods Approaches. California: Sage Publications Inc, 2008.

[22] D. Groat, L. dan Wang, Architectural Research Methods. New York: John Wiley \& Sons Inc, 2002.

[23] I. N. Sumaryadi, Perencanaan Pembangunan Daerah Otonom dan Pemberdayaan Masyarakat. Jakarta: Penerbit Citra Utama, 2010.

[24] B. Tjokromidjojo, Administrasi Pembangunan. Jakarta: LP3ES, 2000. 